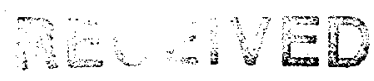

\section{Effects of Air Infiltration on the Effective Thermal Conductivity of Internal Fiberglass Insulation and on the Delivery of Thermal Capacity Via Ducts}

\author{
Ronnen M. Levinson, Wm. Woody Delp, \\ Darryl J. Dickerhoff, Mark P. Modera \\ March 2000 \\ Environmental Energy Technologies Division \\ Lawrence Berkeley National Laboratory \\ University of California \\ Berkeley, CA 94720
}

This work was supported by the Assistant Secretary for Energy Efficiency and Renewable Energy, Office of Building Technology and Community Systems, of the U.S. Department of Energy under Contract No. DE-AC03-76SF00098 and by the California Institute For Energy Efficiency. 
(2) 


\section{DISCLAIMER}

This report was prepared as an account of work sponsored by an agency of the United States Government. Neither the United States Government nor any agency thereof, nor any of their employees, make any warranty, express or implied, or assumes any legal liability or responsibility for the accuracy, completeness, or usefulness of any information, apparatus, product, or process disclosed, or represents that its use would not infringe privately owned rights. Reference herein to any specific commercial product, process, or service by trade name, trademark, manufacturer, or otherwise does not necessarily constitute or imply its endorsement, recommendation, or favoring by the United States Government or any agency thereof. The views and opinions of authors expressed herein do not necessarily state or reflect those of the United States Government or any agency thereof. 


\section{DISCLAIMER}

Portions of this document may be illegible in electronic image products. Images are produced from the best available original document. 


\section{Table Of Contents}

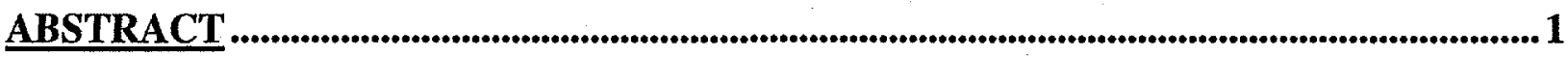

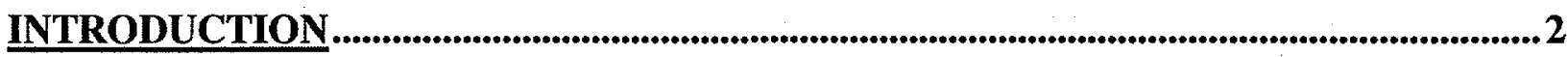

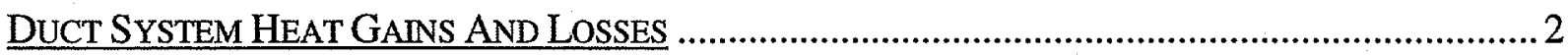

DELIVERY EFFECTIVENESS OF A SUPPLY AIR DUCT ………....................................................

INCREASING EFFECTIVENESS BY PREVENTING INFILTRATION ..................................................... 2

REPORTED MEASUREMENT OF THE CHANGE IN TOTAL THERMAL RESISTANCE DUE TO

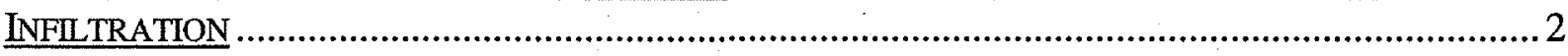

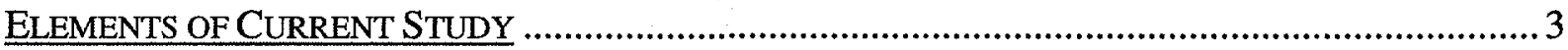

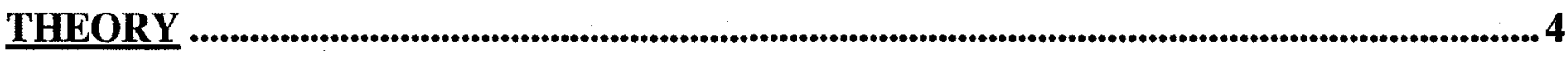

EFFECT OF THERMAL LOSSES FROM DUCT ON THERMAL CAPACITY OF SUPPLY AIR .................... 4

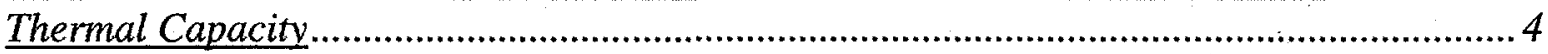

Delivery Effectiveness ................................................................................................ 4

Influence Of Thermal Resistance On Delivery Effectiveness................................................... 4

VARIATION OF THE EFFECTIVE THERMAL CONDUCTIVTTY OF FIBERGLASS INSULATION WITH

TEMPERATURE AND DUCT AIR SPEED ………………….........................................................

Variation Of Total Resistance With Insulation's Effective Thermal Conductivity ..................5

Variation With Temperature And Duct Air Speed Of Insulation Conductivity........................ 5

Variation With Permeability Of Velocity Sensitivity.............................................................. 5

INCREASING EFFECTIVENESS BY PREVENTING INFLLTRATION OF INTERNAL FIBERGLASS DUCT

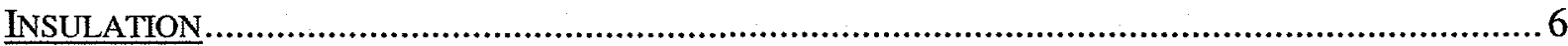

Encapsulating Insulation To Prevent Degradation Of Thermal Resistance............................. 6

Parameters Influencing Magnitude Of Effectiveness Gain ....................................................... 6

DETERMINING SENSITIVITY OF EFFECTIVE THERMAL CONDUCTIVITY TO DUCT AIR SPEED …….7

EXPERIMENTAL MEASUREMENT OF PERMEABILITIES OF FLEXIBLE-DUCT AND RIGID-DUCT FIBERGLASS INSULATIONS.................................................................... 8

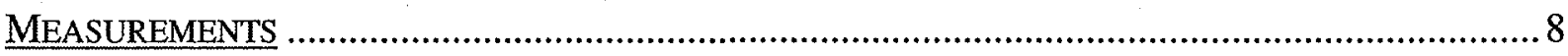

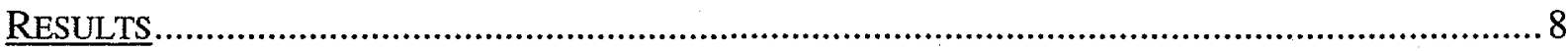

EXPERIMENTAL MEASUREMENT OF THE CONDUCTIVITY OF FIBERGLASS INSULATION VS. DUCT AIR SPEED...............................................................................................9

OVERVIEW

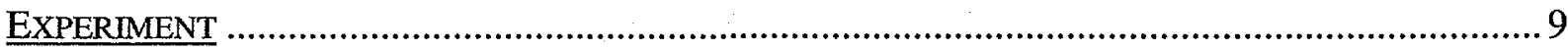

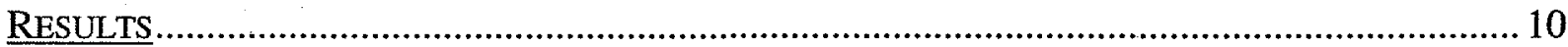

Variation of Conductivity With Duct Air Speed ............................................................... 10

Variation of Total Conductance With Air Speed...................................................................... 13

SIMULATED EFFECTIVENESS GAINS OF TYPICAL SUPPLY DUCTS........................ 15

OVERVIEW

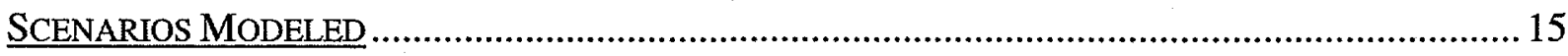

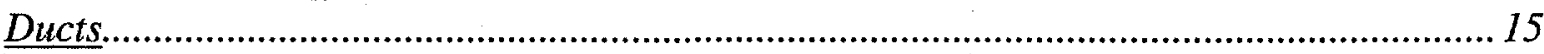




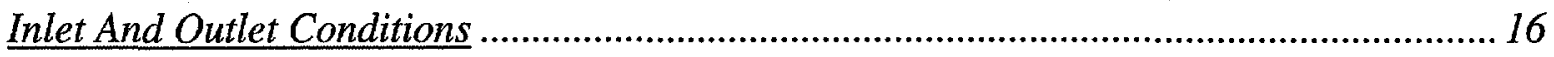

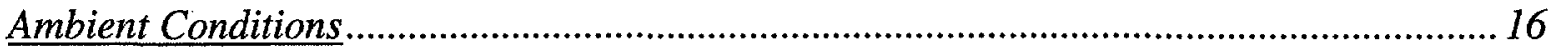

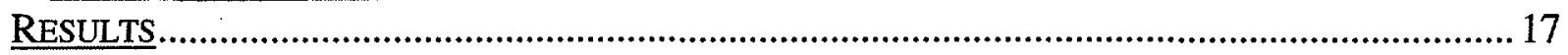

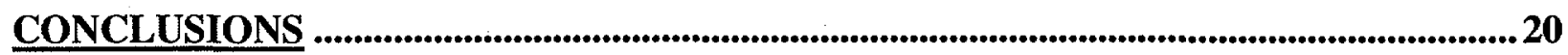

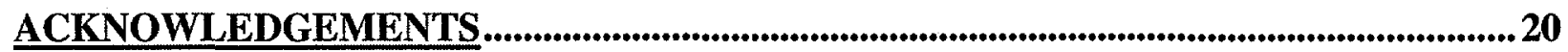

REFERENCES

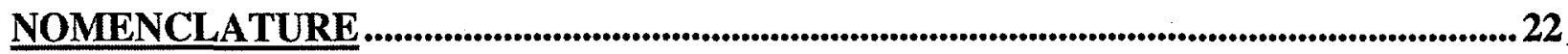

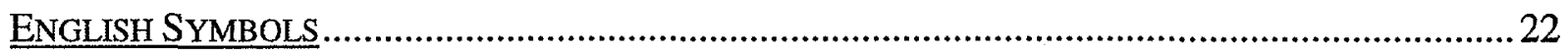

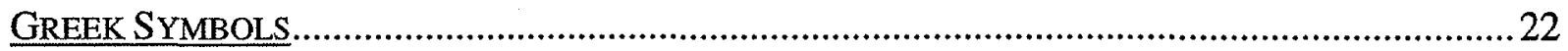

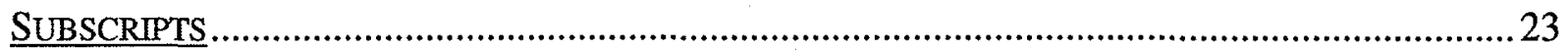

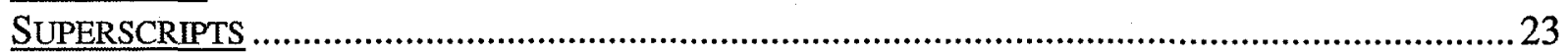

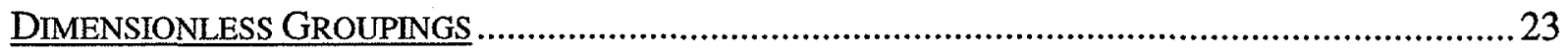

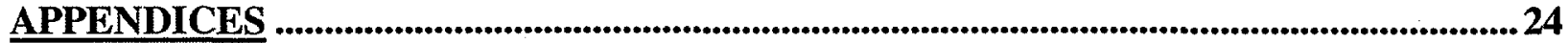

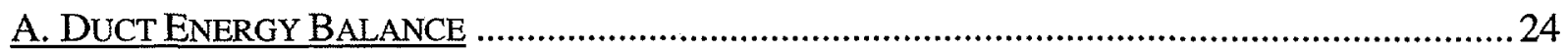

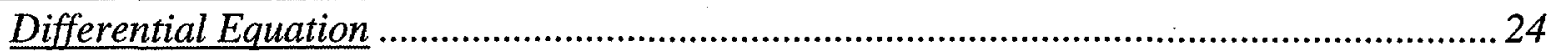

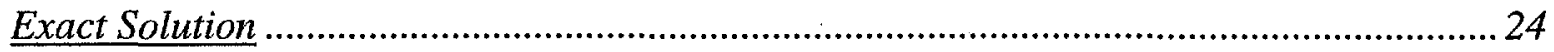

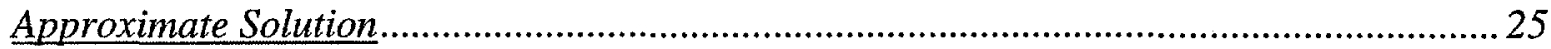

B. VARIATION OF FIBERGLASS CONDUCTTVITY WITH PERMEABIITY AND DUCT AIR SPEED ....25

C. THERMAL RESISTANCES OF AN INTERNALLY-INSULATED DUCT ............................................2.

Total Resistance Of An Arbitrarily-Shaped Duct...................................................................2. 26

Air-Film And Insulation Resistances Of A Cylindrical Duct ..................................................2. 26

Air-Film And Insulation Resistances Of A Non-Cylindrical Duct .......................................26

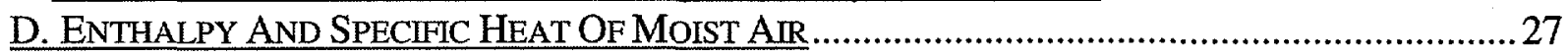

E. EMPIRICAL RELATIONS FOR AIR-FILM HEAT TRANSFER COEFFICIENTS.................................22

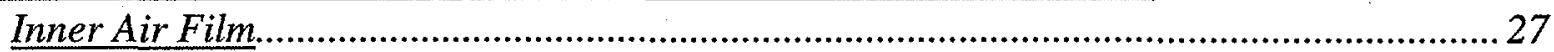

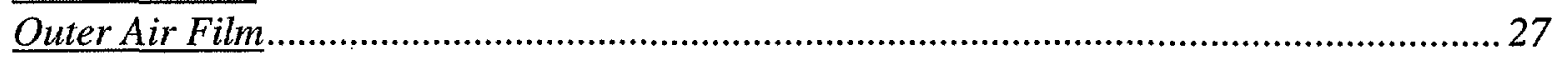




\section{Abstract}

A supply-air duct may contain a fiberglass lining for acoustic control and thermal insulation. As conditioned air travels through the duct, heat exchange between the air and the duct's surroundings reduces the air's "thermal capacity," or rate at which it can heat or cool the space to which it is delivered. Increasing the thermal resistance of the duct's insulation will reduce the thermal loss from the duct, and thereby raise the supply air's thermal capacity at the duct's outlet.

Air flowing through a duct will infiltrate internal fiberglass insulation if the insulation's airfacing surface is pervious. Infiltration induces forced convection within the fiberglass, raising its effective thermal conductivity and lowering its thermal resistance. Encapsulating the air-facing surface with an impervious barrier prevents infiltration of the insulation and degradation of its thermal resistance.

The effectiveness with which a duct delivers thermal capacity is the ratio of the supply air's thermal capacity at the outlet to that at the inlet. The increase in effectiveness induced by encapsulating the insulation's surface is the duct's "effectiveness gain." Given the variation with duct air speed of the insulation's conductivity, a duct's effectiveness gain can be calculated for arbitrary duct geometries, duct air speeds, and exterior conditions.

This study determined the air-speed dependence of the conductivity of fiberglass insulation by measuring the inlet-to-outlet temperature drop of heated air as it traveled at various speeds through a long, insulated flexible duct. The measured conductivity of a flexible duct's lowdensity, internal, fiberglass-blanket insulation increased with the square of the duct air speed, rising by $140 \%$ as the duct air speed increased from 0 to $15 \mathrm{~m} \mathrm{~s}^{-1}$. At air speeds recommended for branch ducts, the conductivity of infiltrated, low-density, flexible-duct insulation would increase by $6 \%$ above its still-air value in a residential system, and by $16 \%$ in a commercial system. The variation with air speed of the insulated flexible duct's total conductance (insulation plus air films) was in partial agreement with that reported by an earlier study.

The conductivity of the high-density fiberglass insulation that is typically installed in rigid main ducts was inconvenient to measure with the temperature-drop technique. However, based on permeability measurements, theoretical analysis suggests that the conductivity of high-density insulation increases with the square of duct air speed at about half the rate observed for lowdensity insulation. That is, it rises by $66 \%$ as the duct air speed increases from 0 to $15 \mathrm{~m} \mathrm{~s}^{-1}$. At air speeds recommended for main ducts, the conductivity of high-density rigid-duct insulation would increase by 4 to $6 \%$ above its still-air value in a residential system, and by 11 to $29 \%$ in a commercial system.

Simulations indicate that encapsulating the air-stream surface of internal fiberglass duct insulation with an impervious barrier increases the effectiveness with which a duct delivers the thermal capacity of supply air by 0.1 to $0.9 \%$ in typical duct systems. Efficiency gains in commercial systems were approximately twice those in residential systems because the former operate at higher duct air speeds. Gains decrease with duct diameter, and increase with duct air speed, duct length, magnitude of the difference in temperature between the supply air and the duct's surroundings, and the sensitivity of the insulation's conductivity to duct air speed. 


\section{Introduction}

\section{DUCT SYSTEM HEAT GAINS AND LOSSES}

Heat gains and losses to duct systems in residential and commercial buildings have been shown to strongly influence the energy efficiency with which conditioned air is delivered to the occupied space. Based both on measurement and simulation, Palmiter and Francisco (1997) estimated that heat pump systems in the Pacific Northwest might suffer a $10 \%$ increase in seasonal energy requirements from conduction losses from ducts located in crawlspaces. In a very different climate, Parker et al. (1993) predicted through a detailed simulation that peak residential duct system heat gains could approach $33 \%$ of available cooling system capacity under peak conditions when ducts were located in an attic. Jump et al. (1996) performed detailed measurements that determined that supply-duct conduction reduced residential space conditioning efficiency by $16 \%$ in California homes tested.

\section{DELIVERY EFFECTIVENESS OF A SUPPLY AIR DUCT}

A supply-air duct may contain a fiberglass lining for acoustic control and thermal insulation. As conditioned air travels through a supply duct, heat exchange between the air and the duct's surroundings reduces the air's "thermal capacity," or rate at which it can heat or cool the space to which it is delivered. The magnitude of this thermal loss is inversely proportional to the duct's total thermal resistance, which is the sum of the resistance of the duct's insulated wall and the resistances of the boundary-layer air films inside and outside the duct's wall. Increasing the resistance of the duct's insulation will reduce the thermal loss from the duct, and thereby raise the supply air's thermal capacity at the duct's outlet.

\section{INCREASING EFFECTIVENESS BY PREVENTING INFILTRATION}

Air flowing through a duct will infiltrate internal fiberglass insulation if the insulation's airfacing surface is pervious. Infiltration induces forced convection within the fiberglass, raising its effective thermal conductivity and lowering its thermal resistance. Encapsulating the insulation's air-facing surface with an impervious barrier prevents infiltration of the insulation and degradation of its thermal resistance.

The effectiveness with which a duct delivers thermal capacity is the ratio of the supply air's thermal capacity at the outlet to that at the inlet. The increase in effectiveness induced by encapsulating the insulation's surface is the duct's "effectiveness gain." Given the variation with air speed of its insulation's conductivity, a duct's effectiveness gain can be calculated for arbitrary duct geometries, duct air speeds, and exterior ambient conditions.

\section{REPORTED MEASUREMENT Of The Change In TOTAL ThERMAL RESistance DUE TO INFILTRATION}

Only one report of the variation with duct air speed of the total resistance of fiberglass-insulated ductwork was found in the literature. Lauvray (1978) reported that the total conductance of a flexible duct with internal fiberglass insulation was invariant at air speeds below $5 \mathrm{~m} \mathrm{~s}^{-1}$, and rose 
linearly with air speed at speeds above $5 \mathrm{~m} \mathrm{~s}^{-1}$. The study did not report the diameter of the duct, the thickness of its insulation, the emissivity of its outer surface, or the speed and temperature of the ambient air. Thus, it is difficult to generalize the reported variation of total thermal resistance, or to calculate the variation with air speed of the insulation's thermal conductivity. No reports of the variation with duct air speed of the conductivity of internal fiberglass insulation were found.

\section{ELEMENTS OF CURRENT STUDY}

This study determined the air-speed dependence of the conductivity of fiberglass insulation by measuring the inlet-to-outlet temperature drop of heated air as it traveled at various speeds through a long, insulated flexible duct. The results were used to simulate the effectiveness gains obtainable by encapsulating the air-facing surface of the insulation in ducts in residential and commercial systems. The simulations modeled flexible and rigid ducts, hot and cold air supplies, and duct locations inside and outside the building's thermal envelope.

The temperature-drop conductivity measurement technique requires a long, narrow duct to obtain a good ratio of signal to noise in the temperature difference. Flexible branch ducts are manufactured in lengths of up to $15 \mathrm{~m}$, and are typically insulated with low-density fiberglass blankets. Rigid main ducts-e.g., rectangular sheet-metal trunk ducts-are typically insulated with high-density fiberglass blankets, and are not usually manufactured in long lengths. The high-density blankets are less permeable to air than are low-density blankets, and their conductivities are expected to vary less with duct air speed.

Since it was more convenient to obtain a long run of insulated flexible duct than a long run of insulated rigid duct, the conductivity measurements were performed on low-density, flexible-duct insulation. The permeabilities of the low- and high-density blankets were measured, and their ratio used to theoretically extrapolate the air-speed variation of the conductivity of the highdensity, rigid-duct insulation from that measured for the low-density blanket. 


\section{Theory}

\section{EFFECT OF THERMAL LOSSES FROM DUCT ON THERMAL CAPACITY OF SUPPLY AIR}

\section{Thermal Capacity}

To maintain the air in a conditioned room at constant temperature and humidity, the room's net influx of enthalpy from the inflow of supply air and outflow of room air must equal its net thermal load. If the room's air flow is balanced,

$$
\dot{m}_{a} H-\dot{m}_{a} H_{R}=Q_{\text {room }},
$$

where $Q_{\text {room }}$ is the room's net thermal load, $\dot{m}_{a}$ is the mass flow rate of the dry-air component of the supply air, and $H$ and $H_{R}$ are the enthalpies per unit mass dry air of the supply air and room air. This net enthalpy influx is the supply's air "thermal capacity,"

$$
C \equiv \dot{m}_{a}\left(H-H_{R}\right) \text {. }
$$

\section{Delivery Effectiveness}

The effectiveness with which a duct delivers capacity is defined as the ratio of the capacity at its outlet, $C_{B}$, to the capacity at its inlet, $C_{A}$. If the duct is airtight and free of internal condensation, its delivery effectiveness is

$$
\varepsilon_{C} \equiv \frac{C_{B}}{C_{A}}=\frac{\dot{m}_{a}\left(H_{B}-H_{R}\right)}{\dot{m}_{a}\left(H_{A}-H_{R}\right)}=1-\frac{H_{A}-H_{B}}{H_{A}-H_{R}}=1-\frac{c_{p}\left(T_{A}-T_{B}\right)}{H_{A}-H_{R}},
$$

where $T_{A}$ and $T_{B}$ are the temperatures at inlet and outlet, and $c_{p}$ is the air's specific heat per unit mass.

\section{Influence Of Thermal Resistance On Delivery Effectiveness}

The duct's delivery effectiveness is related by an energy balance to its "total resistance," $R$, or resistance to heat transfer from the air in the duct to the duct's surroundings:

$$
\varepsilon_{C}=1-\frac{c_{p}[1-\exp (-\Re / R)]\left(T_{A}-T_{\infty}\right)}{H_{A}-H_{R}},
$$

where $T_{\infty}$ is the temperature of the duct's surroundings, $\Re=4 \ell /\left(\rho_{a} c_{p} v d_{h, i}\right)$ is a characteristic thermal resistance, $\ell$ is the length of the duct, $\rho_{a}$ is the density of dry air, $v$ is the bulk velocity of air flow through the duct, $d_{h, i} \equiv 4 A_{i} / P_{i}$ is the duct's inner hydraulic diameter, $A_{i}$ is the duct's inner cross-sectional area, and $P_{i}$ is the duct's inner perimeter. The duct's energy balance is presented in Appendix A.

Increasing the duct's total resistance from $R$ to $R^{\prime}$ will increase its delivery effectiveness by 


$$
\Delta \varepsilon_{C} \equiv \varepsilon_{C}\left(R^{\prime}\right)-\varepsilon_{C}(R)=\frac{c_{p}\left(T_{A}-T_{\infty}\right)}{H_{A}-H_{R}}\left[\exp \left(-\Re / R^{\prime}\right)-\exp (-\Re / R)\right] .
$$

This increase in effectiveness is denoted the duct's "effectiveness gain."

\section{VARIATION OF THE EFFECTIVE THERMAL CONDUCTIVITY OF FIBERGLASS INSULATION WITH TEMPERATURE AND DUCT AIR SPEED}

\section{Variation Of Total Resistance With Insulation's Effective Thermal Conductivity}

The total resistance $R$ of a fiberglass-insulated duct is the sum of the inner air film resistance $R_{i}$, the insulation resistance $R_{f}$, and the outer air film resistance $R_{o}$ :

$$
R=R_{i}+R_{f}+R_{o} .
$$

The thickness and resistance of the duct wall are each at least an order of magnitude smaller than those of the fiberglass insulation, and may be neglected in the thermal analysis.

The insulation's resistance is inversely proportional to its effective thermal conductivity, $k_{f}$. Thus, lowering the insulation's effective thermal conductivity (or "conductivity", for short) will increase the insulation's resistance, the duct's total resistance, and the duct's delivery effectiveness.

\section{Variation With Temperature And Duct Air Speed Of Insulation Conductivity}

The conductivity of infiltrated internal fiberglass duct insulation varies with both fiberglass temperature and duct air speed. Over the temperature range of interest to HVAC applications say, 0 to $50^{\circ} \mathrm{C}$-the conductivity of fiberglass increases approximately linearly with its mean temperature $\bar{T}_{f}$. Theory and measurements developed in this study indicate that the conductivity of infiltrated insulation increases linearly with the square of the duct air speed. Thus, if the conductivity varies independently with temperature and duct air speed,

$$
k_{f}\left(\bar{T}_{f}, v\right)=k_{f 0}^{*}\left[1+\gamma_{T}\left(\bar{T}_{f}-T^{*}\right)\right]\left[1+\gamma_{v} v^{2}\right],
$$

where $\gamma_{T}$ and $\gamma_{v}$ are the sensitivities of the insulation's effective thermal conductivity to temperature and velocity, and $k_{f 0}^{*}$ is the still-air conductivity of fiberglass insulation at reference mean temperature $T^{*}=24^{\circ} \mathrm{C}$.

\section{Variation With Permeability Of Velocity Sensitivity}

The permeability to a fluid of a porous medium, $\kappa$, is the ratio of the fluid's bulk-flow velocity through the medium, $v_{f}$, to the magnitude of the pressure gradient across the medium, $|d p / d z|$ :

$$
\kappa=\frac{v_{f}}{|d p / d z|}
$$


Flow analysis suggests that the velocity-sensitivity $\gamma_{v}$ is proportional to the insulation's permeability to air. Thus, if the measured velocity sensitivity of an insulation of permeability $\kappa_{l}$ is $\gamma_{v, 1}$, the extrapolated velocity sensitivity of an insulation of permeability $\kappa_{2}$ is

$$
\gamma_{v, 2}=\left(\kappa_{2} / \kappa_{1}\right) \gamma_{v, 1}
$$

The flow analysis is presented in Appendix B.

\section{INCREASING EFFECTIVENESS BY PREVENTING INFILTRATION OF INTERNAL FIBERGLASS DUCT INSULATION}

\section{Encapsulating Insulation To Prevent Degradation Of Thermal Resistance}

Consider a perviously-faced fiberglass blanket of still-air conductivity $k_{f 0}$. When it is installed inside a duct, air flowing through the duct can infiltrate the fiberglass, inducing forced convection within the insulation that increases its conductivity to some value $k_{f}(v)>k_{f 0}$. Encapsulating the air-facing surface of the insulation with an impervious barrier will prevent infiltration, lowering the insulation's conductivity at a given duct air speed from $k_{f}=k_{f}(v)$ to $k_{f}^{\prime}=k_{f 0}$. Encapsulation thereby increases both the insulation resistance and the total resistance by

$$
\Delta R=\Delta R_{f}=r_{i} \ln \left(r_{o} / r_{i}\right)\left(1 / k_{f}^{\prime}-1 / k_{f}\right)=\frac{r_{i} \ln \left(r_{o} / r_{i}\right)}{k_{f 0}}\left[\frac{\gamma_{v} v^{2}}{1+\gamma_{v} v^{2}}\right],
$$

where $r_{i}$ and $r_{o}$ are the duct's inner and outer radii. The effectiveness gain is given by Eq. (5), where $R^{\prime}=R+\Delta R$. The relation between the insulation's conductivity and its resistance is presented in Appendix C.

\section{Parameters Influencing Magnitude Of Effectiveness Gain}

When the magnitude of the inlet-to-outlet temperature difference is much smaller than the magnitude of the temperature difference between the duct air and the duct's surroundings, the effectiveness may be approximated by Eq. (A-8). In that case, the effectiveness gain is approximately

$$
\Delta \varepsilon_{C} \approx-\frac{4 \ell\left(T_{A}-T_{\infty}\right) \Delta U}{\rho_{a} d_{h, i} v\left(H_{A}-H_{R}\right)},
$$

where $U=1 / R$ is the duct's total thermal conductance, and $\Delta U=U^{\prime}-U$ is the change in total conductance induced by encapsulation. The approximate effectiveness gain is proportional to both the duct length $\ell$ and the inlet-to-ambient temperature difference $\left(T_{A}-T_{\infty}\right)$, and inversely proportional to both the duct's inner hydraulic diameter $d_{h, i}$ and the inlet-to-room enthalpy difference $\left(H_{A}-H_{R}\right)$. 


\section{DETERMINING SENSITIVITY OF EFFECTIVE THERMAL CONDUCTIVITY TO DUCT AIR}

SPEED

An energy balance relates the duct's total thermal resistance $R$ to measured values of its inlet, outlet, and ambient air temperatures. The insulation's thermal resistance can be found by subtracting the air film resistances from the total resistance. Then, the insulation's conductivity can be calculated from the insulation's resistance (see Appendix C). Since the variation with temperature of the conductivity of fiberglass is known (ASHRAE 1997, p. 24.18), the velocity sensitivity $\gamma_{v}$ and the still-air, reference-temperature conductivity $k_{f 0}^{*}$ of the insulation can be determined by measuring $k_{f}^{*}(v)$ over a range of air speeds, then regressing a function of the form of Eq. (7) to the data. 


\section{Experimental Measurement Of Permeabilities Of Flexible-Duct And Rigid-Duct Fiberglass Insulations}

\section{MEASUREMENTS}

Permeability can be measured by blowing a fluid through a medium, measuring the volumetric rate of flow through and pressure difference across the medium, and dividing the bulk velocity by the pressure gradient.

The permeability to air of a high-density fiberglass blanket (thickness $2.5 \mathrm{~cm}$; density $24 \mathrm{~kg} \mathrm{~m}-3$; flat-form nominal thermal resistance $0.63 \mathrm{~m} 2 \mathrm{~K} \mathrm{~W}-1$ [ $3.6 \mathrm{hr} \mathrm{ft} 2 \mathrm{~F} \mathrm{Btu}-1]$ ) was determined by clamping the blanket to the outlet of a $25-\mathrm{cm}$ diameter duct, blowing air into the duct, and recording the pressure drop across the blanket (duct pressure minus room pressure) at various flow rates.

The permeability of the fabric-core flexible duct's blanket (with fabric-core facing) was determined by closing the outlet of the flexible duct, blowing air into its inlet, exhausting air through an unjacketed patch of blanket, and recording the pressure drop across the liner (duct pressure minus room pressure) at various flow rates.

\section{RESULTS}

At pressure gradients ranging from 2 to $18 \mathrm{~Pa} \mathrm{~cm}^{-1}$, the permeabilities of the high-density and low-density blankets were approximately $1.8 \mathrm{~cm}^{2} \mathrm{~Pa}^{-1} \mathrm{~s}^{-1}$ and $3.6 \mathrm{~cm}^{2} \mathrm{~Pa}^{-1} \mathrm{~s}^{-1}$, respectively. Thus, the permeability to air of the high-density blanket was about half that of the low-density blanket. 


\section{Experimental Measurement Of The Conductivity Of Fiberglass Insulation Vs. Duct Air Speed}

\section{OVERVIEW}

The total resistance of a long, flexible duct with internal fiberglass insulation was measured by blowing hot air though the duct at various speeds, then measuring the air's bulk velocity and the steady-state values of the duct inlet, duct outlet, and ambient air temperatures. These data were used to compute (a) the duct's total resistance $R$ and (b) the insulation's resistance $R_{f}$, conductivity $k_{f}$, reference-temperature conductivity $k_{f}^{*}$, still-air reference-temperature conductivity $k_{f 0}^{*}$, and velocity sensitivity $\gamma_{v}$. The conductivities of both perviously- and imperviously-faced fiberglass blankets were measured with the expectation that the former would vary with air speed, while the latter would remain constant.

\section{EXPERIMENT}

Air was heated to temperatures ranging from 32 to $47^{\circ} \mathrm{C}$, then blown at bulk speeds of 1 to $16 \mathrm{~m} \mathrm{~s}^{-1}$ into a $15-\mathrm{m}$ length of fiberglass-insulated flexible duct. The duct's inner and outer diameters were $15 \mathrm{~cm}$ and $21 \mathrm{~cm}$, respectively. The duct rested on a carpeted floor, and was pulled taut in a U-configuration (Figure 1).

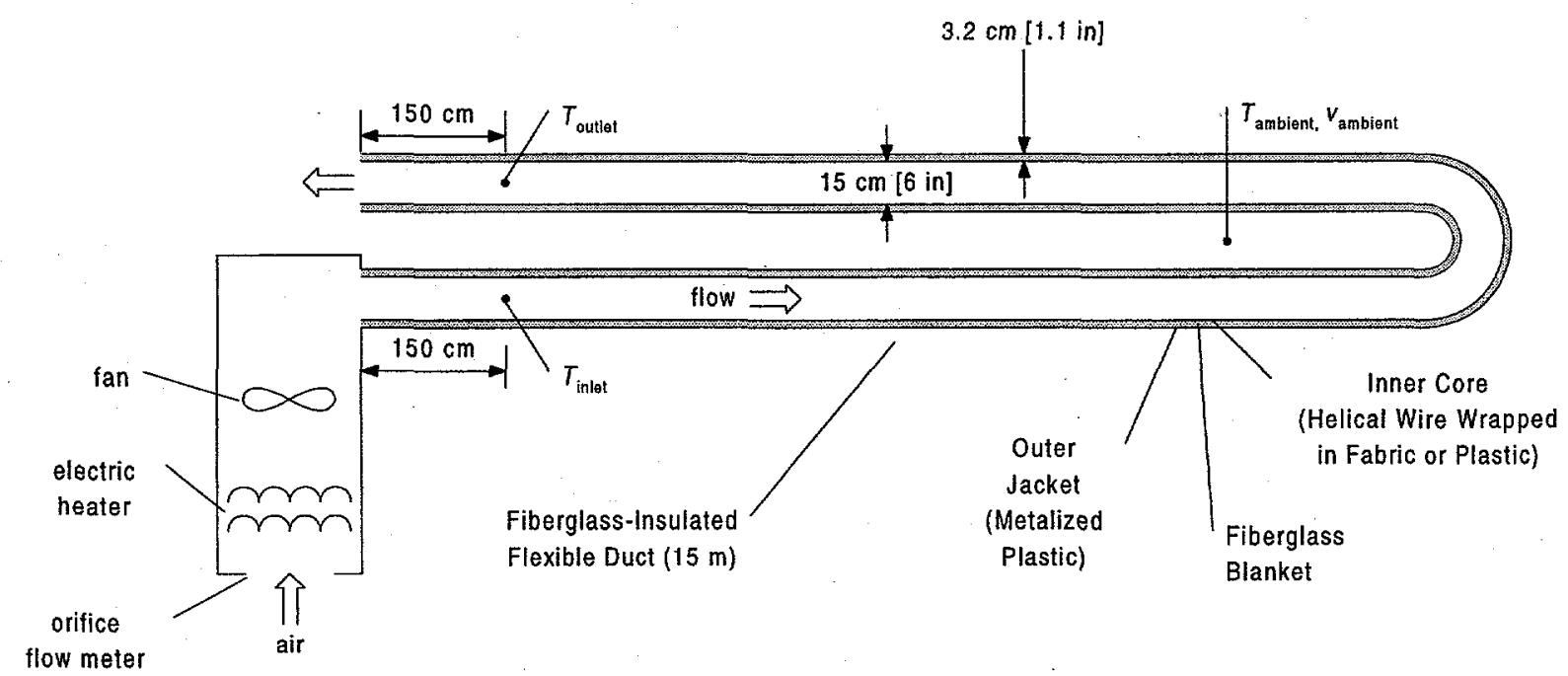

Figure 1. Heater, fan, and insulated flexible duct used to measure the effect of infiltration on the effective thermal conductivity of fiberglass duct insulation.

Steady-state values of (a) the duct's inlet air temperature and (b) the difference between the duct's inlet and outlet air temperatures were measured with a pair of resistance temperature detection (RTD) probes (differential mode accuracy $\pm 0.03{ }^{\circ} \mathrm{C}$ ). Temperatures were considered steady when, after a period of 20 to 60 minutes, the fluctuation in temperature difference fell to $0.1^{\circ} \mathrm{C}$. 
The inlet and outlet temperatures were measured along the duct's centerline, approximately 10 inner diameters $(1.5 \mathrm{~m})$ inwards of the duct's ends. The inlet-to-outlet drop in air temperature ranged from 0.3 to $5.4^{\circ} \mathrm{C}$, varying with the inlet air temperature and duct air speed. The ambient air temperature and velocity were measured with a hot wire anemometer (accuracy $\pm 0.3^{\circ} \mathrm{C}$, $\pm 0.1 \mathrm{~m} \mathrm{~s}^{-1}$ ), and ranged from 21 to $26^{\circ} \mathrm{C}$ and 0.0 to $0.1 \mathrm{~m} \mathrm{~s}^{-1}$, respectively. The volumetric flow rate through the system was measured with an orifice-type flow meter (accuracy $\pm 5 \%$ ) built into the heater/fan unit.

Separate trials were conducted with fabric-core and plastic-core fiberglass-insulated flexible ducts. Each duct consisted of a 15-cm diameter spring-wire helix frame encapsulated in a thin inner core of either non-woven fabric (thickness $10^{-1} \mathrm{~mm}$; flat-form thermal resistance $10^{-2} \mathrm{~m}^{2} \mathrm{~K} \mathrm{~W}^{-1}$ ) or plastic (thickness $10^{-1} \mathrm{~mm}$; flat-form thermal resistance $10^{-3} \mathrm{~m}^{2} \mathrm{~K} \mathrm{~W}^{-1}$ ). The inner core was surrounded by a fiberglass blanket (thickness $2.9 \mathrm{~cm}$; density $13 \mathrm{~kg} \mathrm{~m}^{-3}$; flat-form nominal thermal resistance $0.74 \mathrm{~m}^{2} \mathrm{~K} \mathrm{~W}^{-1}\left[4.2 \mathrm{hr} \mathrm{ft}^{2} \mathrm{~F} \mathrm{Btu}^{-1}\right]$ ), which was in turn encapsulated in a metalized plastic jacket (thickness $10^{-1} \mathrm{~mm}$; flat-form thermal resistance $10^{-3} \mathrm{~m}^{2} \mathrm{~K} \mathrm{~W}^{-1}$; outersurface long-wave emissivity 0.47 ). The duct's inner core acted as the blanket's air-facing surface.

\section{RESULTS}

\section{Variation of Conductivity With Duct Air Speed}

The reference-temperature conductivity of the imperviously-faced blanket was approximately constant, with a 95\%-confidence-level value of $k_{f}^{*}=0.037 \pm 0.002 \mathrm{~W} \mathrm{~m}^{-1} \mathrm{~K}^{-1}$. The referencetemperature conductivity of the perviously-faced fiberglass blanket rose with the square of the duct air speed in the fashion of Eq. (7). The 95\% confidence-level regressed values of its still-air, reference-temperature conductivity and its velocity sensitivity were $k_{f 0}^{*}=0.041 \pm 0.002 \mathrm{~W} \mathrm{~m}^{-1} \mathrm{~K}^{-1}$ and $\gamma_{v}=0.0062 \pm 0.0005 \mathrm{~s}^{2} \mathrm{~m}^{-2}$ (Figure 2).

The regressed reference-temperature, still-air conductivities of the imperviously- and perviouslyfaced blankets were within $5 \%$ of the blankets' nominal conductivity value $k_{f 0, \text { nom }}^{*}=0.039 \mathrm{~W} \mathrm{~m}^{-1} \mathrm{~K}^{-1}$.

The increase in the conductivity of the flexible duct's perviously-faced, low-density fiberglass blanket is shown as a percentage of its still-air conductivity in Figure 3. Also shown is the conductivity increase with air speed for a high-density, rigid-duct fiberglass blanket, which has been extrapolated from that of the low-density-blanket using Eqs. (7) and (9). 


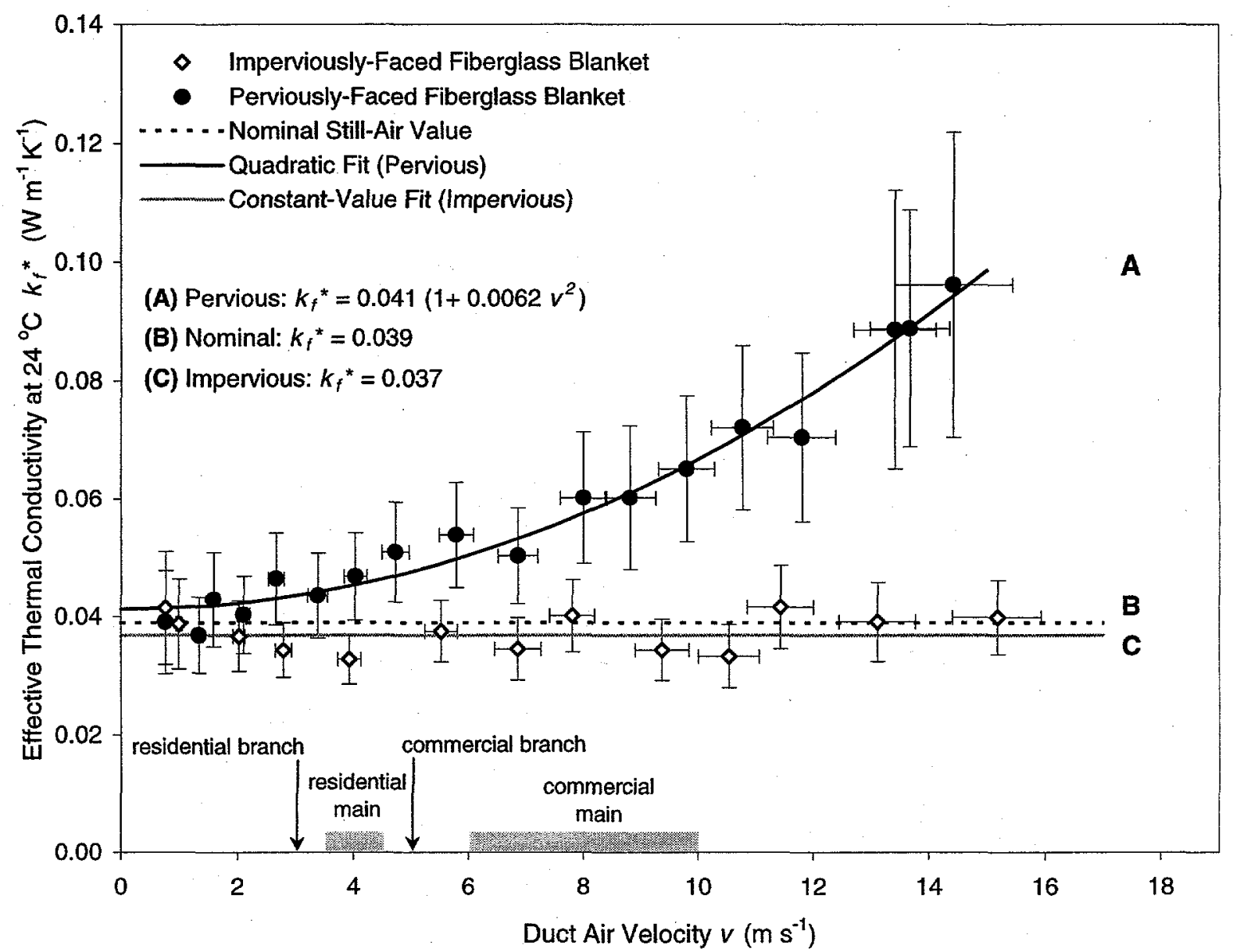

Figure 2. Variation with duct air speed of the effective thermal conductivity at $24 \stackrel{\circ}{\mathrm{C}}$ of perviously- and imperviously-faced fiberglass blankets (density $13 \mathrm{~kg} \mathrm{~m}^{-3}$ ) in flexible ducts. Also shown is the nominal, still-air effective thermal conductivity for both blankets. 


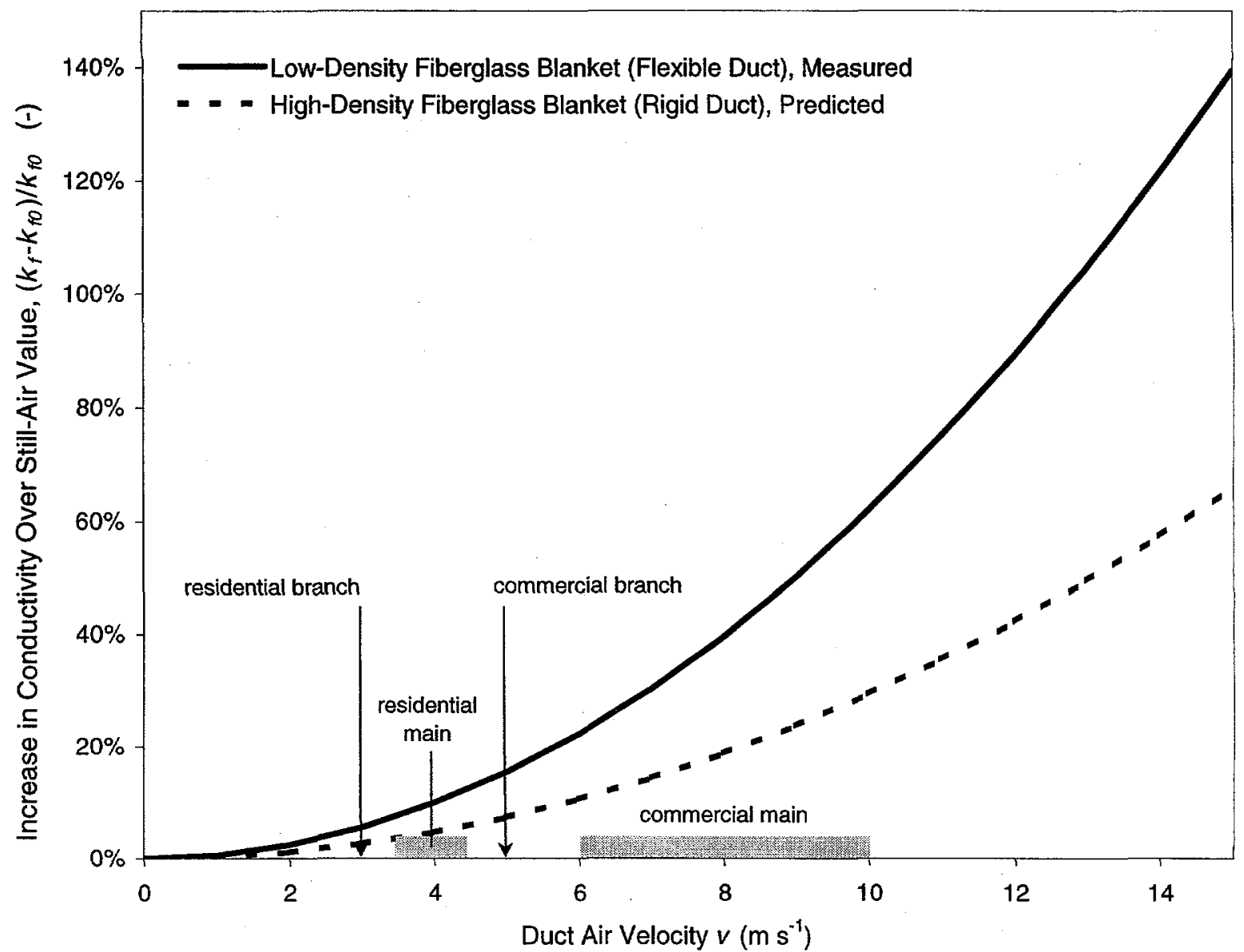

Figure 3. Variation with duct air speed in the infiltration-induced fractional increase of the conductivities. of low-density and high-density fiberglass blankets. The low-density-blanket's conductivity was measured, while the high-density blanket's conductivity was extrapolated from that of the low-density-blanket result using Eqs. (7) and (9).

Table 1 shows air speeds recommended to minimize flow noise in main ducts and branch ducts in residential and commercial systems (SMACNA 1988, p. 6.4). Flexible ductwork is used for branch ducts, while rigid ductwork is used for main ducts. Typical increases in the conductivities of flexible branch-duct insulation and rigid main-duct insulation in residential and commercial systems are presented in Table 2 .

\begin{tabular}{|c|cc|}
\hline Duct Air Speed $\left(\boldsymbol{m} \boldsymbol{s}^{-1}\right)$ & Residential & Commercial \\
\hline Branch Duct & 3 & 5 \\
Main Duct & $3.5-4.5$ & $6-10$ \\
\hline
\end{tabular}

Table 1. Duct air speeds recommended to minimize flow noise (SMACNA, p. 6.4). 


\begin{tabular}{|c|cc|}
\hline Conductivity Increase Due To Infiltration (-) & Residential & Commercial \\
\hline Flexible Branch Duct & $6 \%$ & $16 \%$ \\
Rigid Main Duct & $4-6 \%$ & $11-29 \%$ \\
\hline
\end{tabular}

Table 2. Fractional increases due to infiltration of the conductivities of fiberglass insulation in flexible branch ducts and rigid main ducts in residential and commercial systems, computed for the duct air speeds recommended to minimize noise.

\section{Variation of Total Conductance With Air Speed}

The total conductance of the pervious-core flexible duct increased approximately linearly with air speed, rising from its still-air value of $0.85 \mathrm{~W} \mathrm{~m}^{-2} \mathrm{~K}^{-1}$ by $10 \%$ per $1 \mathrm{~m} \mathrm{~s}^{-1}$ increase in velocity (Figure 4). This partly agrees with the results reported by Lauvray (1978), who found that the total conductance of a pervious-core flexible duct retained its still-air value for air speeds below $5 \mathrm{~m} \mathrm{~s}^{-1}$, but rose by $16 \%$ per $1 \mathrm{~m} \mathrm{~s}^{-1}$ increase in duct air velocity above $5 \mathrm{~m} \mathrm{~s}^{-1}$.

The total thermal conductance of the impervious-core flexible duct increased approximately linearly with air speed, rising from its still-air value of $1.0 \mathrm{~W} \mathrm{~m}^{-2} \mathrm{~K}^{-1}$ by $2 \%$ per $1 \mathrm{~m} \mathrm{~s}^{-1}$ increase in velocity. This slight increase in total conductance with air speed results from the decrease in the resistance of the inner air film.

The projected zero-velocity total conductances of the pervious- and impervious-core flexible ducts were equal to within $5 \%$. 


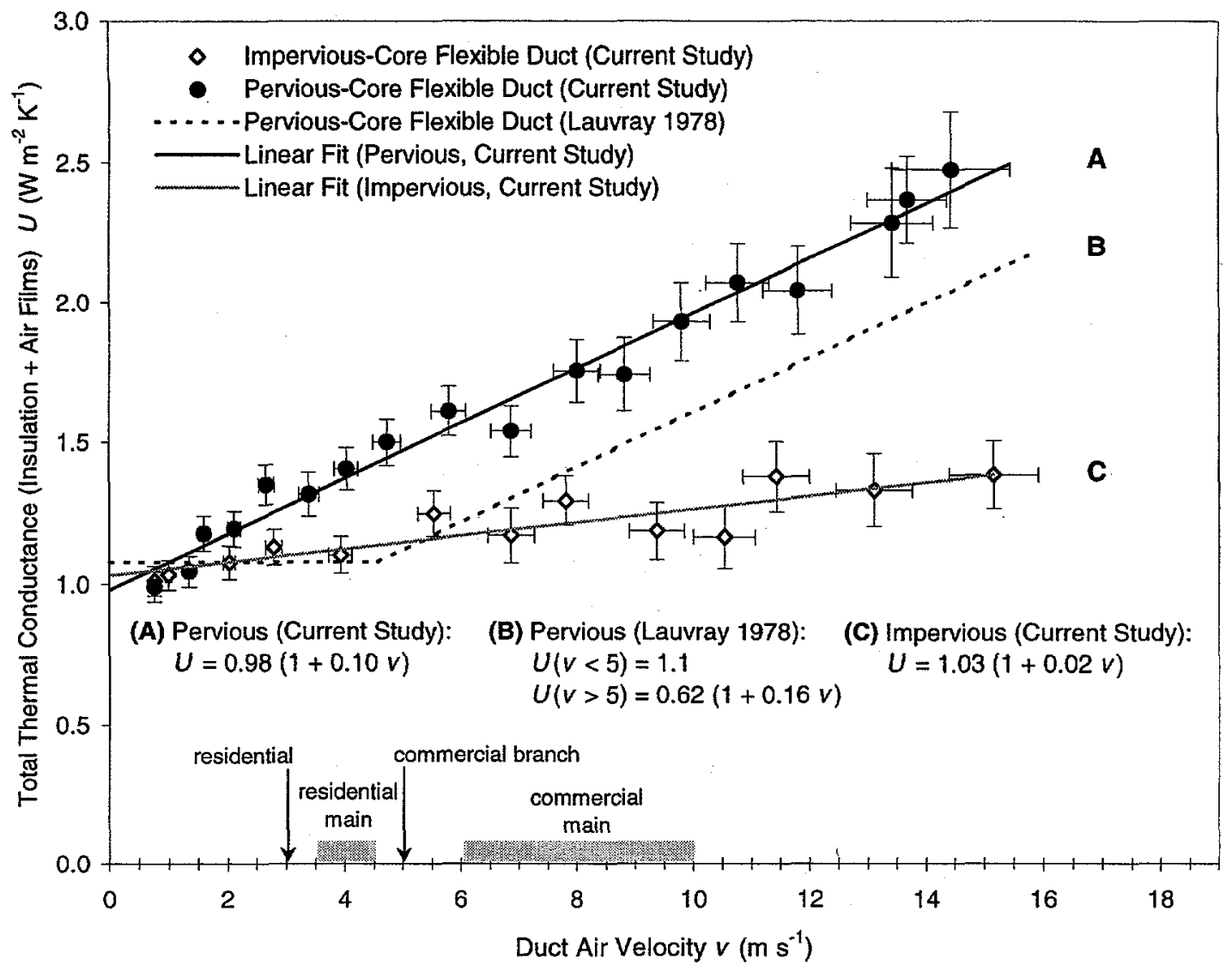

Figure 4. Variation with duct air speed of the total thermal conductance (fiberglass plus air films) of insulated flexible ducts with pervious and impervious inner cores. The ducts have an inner diameter of $15 \mathrm{~cm}(6.0 \mathrm{in})$, internal fiberglass insulation (thickness $2.9 \mathrm{~cm}$; density $13 \mathrm{~kg} \mathrm{~m}^{-3}$; flat-form nominal thermal resistance $0.74 \mathrm{~m}^{2} \mathrm{~K} \mathrm{~W}^{-1}\left[4.2 \mathrm{hr} \mathrm{ft}^{2} \mathrm{~F} \mathrm{Btu}^{-1}\right]$ ), and a metalized plastic outer jacket (long-wave emissivity 0.47 ). Also shown is the total thermal conductance reported by Lauvray (1978) for a pervious-core flexible duct (nominal flatform resistance of fiberglass insulation, $0.77 \mathrm{~m}^{2} \mathrm{~K} \mathrm{~W}^{-1}\left[4.3 \mathrm{hr} \mathrm{ft}^{2} \mathrm{~F} \mathrm{Btu}\right.$ ]; no other information reported). 


\section{Simulated Effectiveness Gains Of Typical Supply Ducts}

\section{OVERVIEW}

The gain in delivery effectiveness achieved by encapsulating the pervious air-facing surface of a supply duct's internal fiberglass insulation depends on duct properties (length, cross-section, and outer surface's long-wave emissivity); insulation properties (thickness, still-air conductivity, and sensitivities of conductivity to temperature and velocity); duct-exterior conditions (air temperature and velocity); inlet-air conditions (temperature and humidity); and room-air conditions (temperature and humidity).

\section{SCENARIOS MODELED}

Effectiveness gain versus air speed was simulated for eight combinations of supply-duct type, supply-air temperature, and supply-duct location:

$$
\left\{\begin{array}{c}
\text { flexible duct } \\
\text { OR } \\
\text { rigid duct }
\end{array}\right\} \times\left\{\begin{array}{c}
\text { hot supply air } \\
\text { OR } \\
\text { cold supply air }
\end{array}\right\} \times\left\{\begin{array}{c}
\text { duct inside thermal envelope } \\
\text { OR } \\
\text { duct outside thermal envelope }
\end{array}\right\} .
$$

Ducts

Supply air is usually transmitted over short distances with flexible branch ducts, and over long distances with rigid main ducts. The first duct modeled was a 7.5-m long, 20-cm inner-diameter, pervious-core flexible branch duct, internally insulated with a low-density fiberglass blanket. The second was a $30-\mathrm{m}$ long, $30 \mathrm{~cm}$ x $21 \mathrm{~cm}$ outer-cross-section, galvanized-steel, rigid main duct, internally insulated with a high-density fiberglass blanket (Table 3 ). 


\begin{tabular}{|c|c|c|}
\hline & $\begin{array}{c}\text { Flexible } \\
\text { Branch Duct }\end{array}$ & $\begin{array}{c}\text { Rigid } \\
\text { Main Duct }\end{array}$ \\
\hline Length (m) & 7.5 & 30 \\
\hline Inner Diameter $(\mathrm{cm})$ & 20 & - \\
\hline Outer Height and Width (cm) & - & $30 \times 91$ \\
\hline Outer-Surface Long-Wave Emissivity (-) & 0.9 & 0.2 \\
\hline Insulation Density $\left(\mathrm{kg} \mathrm{m}^{-3}\right)$ & 13 & 24 \\
\hline Insulation Thickness (cm) & 2.9 & 2.5 \\
\hline $\begin{array}{l}\text { Insulation's Nominal Flat-Form, } \\
\text { Still-Air Thermal Resistance }\left(\mathrm{m}^{2} \mathrm{~K} \mathrm{~W}^{-1}\right)\end{array}$ & 0.74 & 0.63 \\
\hline Velocity Sensitivity Of Insulation Conductivity $\left(\mathrm{s} \mathrm{m}^{-1}\right.$ ) & 0.14 & 0.06 \\
\hline Temperature Sensitivity Of Insulation Conductivity $\left(\mathrm{K}^{-1}\right)$ & 0.0047 & 0.0018 \\
\hline
\end{tabular}

Table 3. Properties of modeled flexible and rigid ducts.

\section{Inlet And Outlet Conditions}

Supply ducts may deliver either hot or cold air to a conditioned room. Hot and cold plenum air temperatures and humidities were chosen to represent typical HVAC operating conditions, while the room air temperatures and humidities were chosen to lie within the human comfort zone (ASHRAE 1997, p. 8.12).

Ambient Conditions

If a supply duct is located within the room's thermal envelope-e.g., in a ceiling space that serves as a return plenum - heat from light fixtures may raise the duct's ambient air temperature several degrees Celsius above room air temperature. If the supply duct lies outside the room's thermal envelope, its ambient air temperature may be close to the outside air temperature (Table 4). 


\begin{tabular}{|c|cccc|}
\hline & $\begin{array}{c}\text { Cooling Duct } \\
\text { Inside Thermal } \\
\text { Envelope }\end{array}$ & $\begin{array}{c}\text { Cooling Duct } \\
\text { Outside } \\
\text { Thermal } \\
\text { Envelope }\end{array}$ & $\begin{array}{c}\text { Heating Duct } \\
\text { Inside Thermal } \\
\text { Envelope }\end{array}$ & $\begin{array}{c}\text { Heating Duct } \\
\text { Outside } \\
\text { Thermal } \\
\text { Envelope }\end{array}$ \\
\hline Room Air Temperature $\left({ }^{\circ} \mathbf{C}\right)$ & 25 & 25 & 22 & 22 \\
Room Air Humidity Ratio (-) & 0.010 & 0.010 & 0.005 & 0.005 \\
Plenum Air Temperature $\left({ }^{\circ} \mathbf{C}\right)$ & 13 & 13 & 55 & 55 \\
Plenum Air Humidity Ratio (-) & 0.009 & 0.009 & 0.005 & 0.005 \\
Ambient Air Temperature ( $\left.{ }^{\mathbf{0}} \mathbf{C}\right)$ & 27 & 45 & 24 & 0 \\
Ambient Air Velocity $\left(\mathrm{m} \mathrm{s}^{\mathbf{- 1}}\right)$ & 0.1 & 0.1 & 0.1 & 0.1 \\
\hline
\end{tabular}

Table 4. Plenum, room, and ambient air conditions for heating and cooling ducts inside and outside of the room's thermal envelope.

\section{RESULTS}

Efficiency gains increased with duct air speed in all eight scenarios (Figure 5 and Figure 6). Efficiency gains for flexible branch ducts and rigid main ducts at air speeds recommended for residential and commercial systems are summarized in Table 5. Gains in commercial systems were approximately twice those of residential systems, because the former operate at higher duct air velocities.

As predicted by Eq. (11), efficiency gains were higher for ducts outside the thermal envelope than for ducts inside the thermal envelope, because the magnitude of the temperature difference between the supply air and the ambient air-approximately $\left|T_{A}-T_{\infty}\right|$-was greater for the former than for the latter. The efficiency gains of hot-air ducts were higher than those of cold-air ducts for the same reason. 


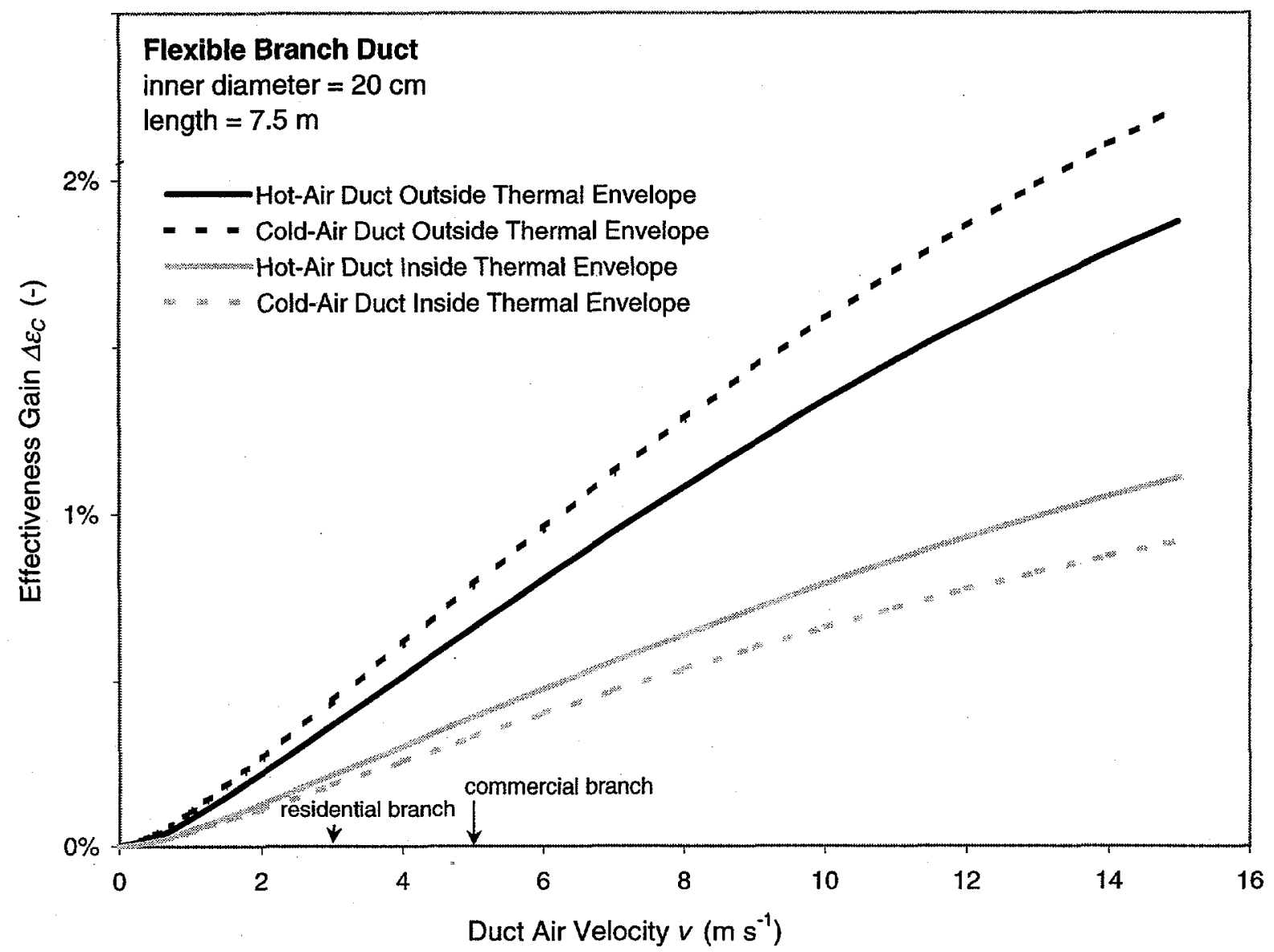

Figure 5. Variation with duct air speed of the effectiveness gain achieved by encapsulating the air-facing surface of the fiberglass-insulated, flexible branch duct described in Table 3. 


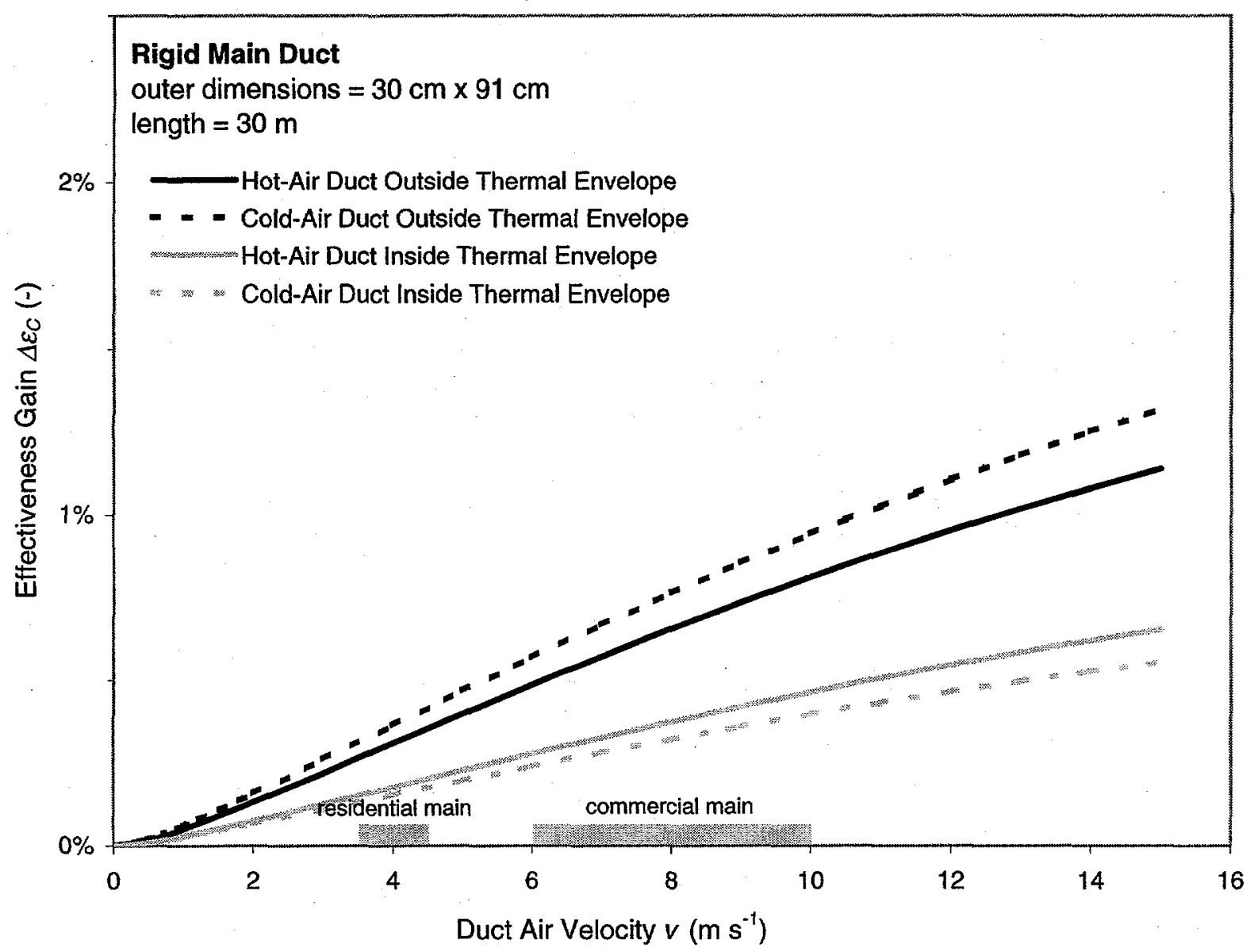

Figure 6. Variation with duct air speed of the effectiveness gain achieved by encapsulating the air-stream surface of the fiberglass-insulated, rigid main duct described in Table 3.

\begin{tabular}{|c|cc|}
\hline Efficiency Gain (-) & Residential & Commercial \\
\hline Flexible Branch Ducts & $0.2-0.4 \%$ & $0.3-0.8 \%$ \\
Rigid Main Ducts & $0.15-0.45 \%$ & $0.2-0.9 \%$ \\
\hline
\end{tabular}

Table 5. Efficiency gains for flexible branch ducts and rigid main ducts at air speeds recommended for residential and commercial systems.

Eq. (11) also predicts that efficiency gain increases with duct length and the sensitivity of insulation conductivity to air speed, and decreases with the duct's inner hydraulic diameter. The rigid duct was longer than the flexible duct, but the flexible duct had a smaller inner hydraulic diameter and had insulation whose conductivity was more sensitive to air speed. The rigid duct's lower emissivity also reduced the magnitude of its conductance change. The net result was that at a given air speed, the flexible duct's efficiency gains were higher than those of the rigid duct. 


\section{Conclusions}

The measured conductivity of a flexible duct's low-density internal fiberglass-blanket insulation increased with the square of the duct air speed, rising by $140 \%$ as the duct air speed increased from 0 to $15 \mathrm{~m} \mathrm{~s}^{-1}$. At air speeds recommended for branch ducts, the conductivity of low-density flexible-duct insulation would increase $6 \%$ above its still-air value in a residential system, and $16 \%$ in a commercial system.

The conductivity of a rigid duct's high-density internal fiberglass insulation is theoretically predicted to increase with the square of the duct air speed at about half the rate of the flexible duct insulation, rising by $66 \%$ as the duct air speed increases from 0 to $15 \mathrm{~m} \mathrm{~s}^{-1}$. At air speeds recommended for main ducts, the conductivity of high-density rigid-duct insulation would increase 4 to $6 \%$ above its still-air value in a residential system, and 11 to $29 \%$ in a commercial system.

The measured total conductance of the pervious-core, insulated flexible duct increased linearly with duct air speed at a rate similar to that reported by an earlier study, but the variation was observed to begin at zero air speed, rather than at $5 \mathrm{~m} \mathrm{~s}^{-1}$ as previously reported.

Simulations indicate that encapsulating the air-stream surface of internal fiberglass duct insulation with an impervious barrier can increase the effectiveness with which a duct delivers the thermal capacity of supply air by 0.15 to $0.9 \%$ in typical duct systems. Efficiency gains in commercial systems were approximately twice those in residential systems because commercial systems operate at higher duct air speeds. Gains decrease with duct diameter, and increase with duct air speed, duct length, magnitude of the difference in temperature between the supply air and the duct's surroundings, and the sensitivity of the insulation's conductivity to duct air speed.

\section{Acknowledgements}

This work was supported by the Assistant Secretary for Energy Efficiency and Renewable Energy, Office of Building Technology and Community Systems, of the U.S. Department of Energy under Contract No. DE-AC03-76SF00098 and by the California Institute For Energy Efficiency. Thanks to Paul Berdahl, William Fisk, and Mor Duo Wang for their assistance in this study. 


\section{References}

ASHRAE. 1997. Handbook of Fundamentals, SI Edition. Atlanta, GA; American Society of Heating, Refrigerating and Air-Conditioning Engineers, Inc.

Incropera, F.P., and DeWitt, D.P. 1990. Introduction to Heat Transfer, second edition. New York; John Wiley \& Sons.

Jump, D.A., I.S. Walker and M.P. Modera. 1996. "Field measurements of efficiency and duct retrofit effectiveness in residential forced air systems." Proceedings of the 1996 ACEEE Summer Study on Energy Efficiency in Buildings. Washington, D.C.; American Council for an Energy Efficient Economy.

Lauvray, T.L. 1978. "Experimental heat transmission coefficients for operating air duct systems." ASHRAE Journal, pp. 69-73 (June).

Palmiter, L. and P. Francisco. 1997. "Development of a practical method for estimating the thermal efficiency of residential forced air distribution systems." Palo Alto, CA; Electric Power Research Institute report EPRI-TR-107744.

Parker, D.S., P.F. Fairey and L. Gu. 1993. "Simulation of the effects of duct leakage and heat transfer on residential space cooling energy use.” Energy \& Buildings, Vol. 20, No. 2, pp. 97 114.

SMACNA. 1988. Installation Standards For Residential Heating and Air Conditioning Systems, $6^{\text {th }}$ Edition. Vienna, VA; Sheet Metal and Air Conditioning Contractors National Association, Inc.

White, F.M. 1988. Heat and Mass Transfer. New York; Addison-Wesley. 


\section{Nomenclature}

\section{ENGLISH SYMBOLS}

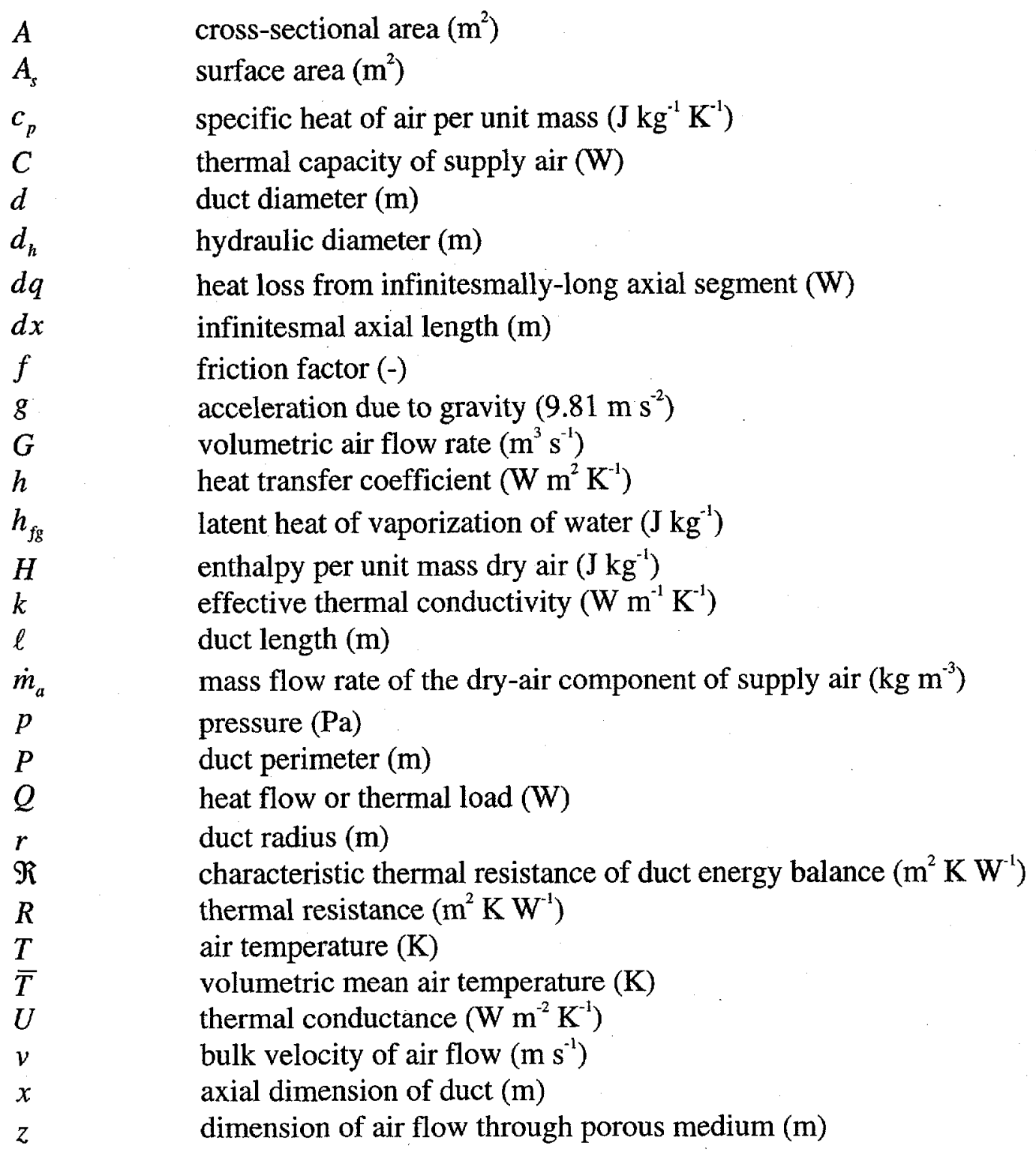

\section{GREEK SYMBOLS}

$\alpha \quad$ thermal diffusivity of air $\left(\mathrm{m}^{2} \mathrm{~s}^{-1}\right)$

$\beta \quad$ thermal expansion coefficient $\left(\mathrm{K}^{-1}\right)$

$\gamma_{T} \quad$ temperature sensitivity of insulation's effective thermal conductivity $\left(\mathrm{K}^{-1}\right)$

$\gamma_{v} \quad$ velocity sensitivity of insulation's effective thermal conductivity $\left(\mathrm{s} \mathrm{m}^{-1}\right)$

$\Delta \varepsilon_{C} \quad$ effectiveness gain (-) 


$\begin{array}{ll}\Delta p & \text { pressure difference }(\mathrm{Pa}) \\ \Delta z & \text { insulation thickness (m) } \\ \varepsilon & \text { emissivity (-) } \\ \varepsilon_{C} & \text { thermal-capacity delivery effectiveness }(-) \\ \varepsilon_{\text {rough }} & \text { surface roughness height }(\mathrm{m}) \\ \kappa & \text { permeability to air of porous medium }\left(\mathrm{m}^{2} \mathrm{~Pa} \mathrm{~s} \mathrm{~s}^{-1}\right) \\ \lambda & \text { characteristic length of duct energy balance }(\mathrm{m}) \\ v_{a} & \text { kinematic viscosity of air }\left(\mathrm{m}^{2} \mathrm{~s}^{-1}\right) \\ \rho & \text { density }\left(\mathrm{kg} \mathrm{m}^{-3}\right) \\ \sigma & \text { Stefan-Boltzmann constant }\left(5.67 \times 10^{-8} \mathrm{~W} \mathrm{~m}^{-2} \mathrm{~K}^{-4}\right) \\ \omega & \text { humidity ratio }(-)\end{array}$

\section{SUBSCRIPTS}

$\begin{array}{ll}a & \text { air } \\ A & \text { duct inlet } \\ B & \text { duct outlet } \\ f & \text { fiberglass } \\ f 0 & \text { fiberglass with still internal air } \\ \text { flat } & \text { flat form } \\ \text { forced } & \text { forced convection } \\ \text { free } & \text { free convection } \\ i & \text { inner wall or inner air film } \\ \text { mixed } & \text { forced and free convection } \\ o & \text { outer wall or outer air film } \\ \text { rad } & \text { radiative } \\ \text { room } & \text { conditioned room } \\ w & \text { water vapor } \\ \infty & \text { duct surroundings }\end{array}$

\section{SUPERSCRIPTS}

* evaluated at reference temperature of $24^{\circ} \mathrm{C}$

\section{DIMENSIONLESS GROUPINGS}

$\begin{array}{ll}\mathrm{Nu} & \text { Nusselt number, } h d / k_{a} \\ \mathrm{Pr} & \text { Prandtl number, } v_{a} / \alpha \\ \mathrm{Ra} & \text { Rayleigh number, } g \beta \Delta T d^{3} /\left(v_{a} \alpha\right) \\ \mathrm{Re} & \text { Reynolds number, } v d / v_{a}\end{array}$




\section{Appendices}

\section{A. DUCT ENERGY BALANCE}

\section{Differential Equation}

Consider an internally-insulated supply-air duct of inner perimeter $P_{i}$, inner cross-sectional area $A_{i}$, and length $\ell$ that carries air at bulk velocity $v$. If no internal condensation occurs, the steady-state energy balance on an infinitesmal duct segment of axial length $d x$ is

$$
\dot{m}_{a}\left(H_{x}-H_{x+d x}\right)=\dot{m}_{a} c_{p}\left(T_{x}-T_{x+d x}\right)=d Q .
$$

Here $T$ is the duct air's bulk temperature, and $d Q$ is the thermal loss from the supply air to the duct's surroundings. If the duct's outer surface is also free of condensation,

$$
d Q=P_{i} d x\left(T_{x}-T_{\infty}\right) / R,
$$

where $T_{\infty}$ is the temperature of both the ambient air and the radiative enclosure outside the duct, and $R$ is the duct's total thermal resistance.

Combining Eqs. (A-1) and (A-2) yields an ordinary differential equation for the duct air's axial temperature profile, $T(x)$ :

$$
\frac{d T}{d x}=-\frac{T-T_{\infty}}{\lambda},
$$

where

$$
\lambda=\frac{\dot{m}_{a} c_{p} R}{P_{i}}=\frac{\rho_{a} c_{p} v A_{i} R}{P_{i}}=\frac{\rho_{a} c_{p} v d_{h, i} R}{4}
$$

is a characteristic length, and $d_{h, i} \equiv 4 A_{i} / P_{i}$ is the duct's inner hydraulic diameter. Note that this energy balances applies to ducts with any constant cross-sectional shape.

\section{Exact Solution}

The solution to Eq. (A-3) for the inlet-to-outlet temperature difference is

$$
T_{A}-T_{B}=[1-\exp (-\ell / \lambda)]\left[T_{A}-T_{\infty}\right]=[1-\exp (-\Re / R)]\left[T_{A}-T_{\infty}\right],
$$

where

$$
\Re=\frac{\ell P_{i}}{\rho_{a} c_{p} v A_{i}}=\frac{4 \ell}{\rho_{a} c_{p} v d_{h, i}}
$$

is a characteristic thermal resistance. Combining Eqs. (3) and (A-4), the duct's delivery effectiveness is 


$$
\varepsilon_{C}=1-\frac{c_{p}[1-\exp (-\Re / R)]\left(T_{A}-T_{\infty}\right)}{H_{A}-H_{R}}
$$

\section{Approximate Solution}

Convenient approximate solutions for $\left(T_{A}-T_{B}\right)$ and $\varepsilon_{C}$ are available in the common situation where the magnitude of temperature change from inlet to outlet, $\left|T_{A}-T_{B}\right|$, is much smaller than the magnitude of the temperature difference between the supply air and the duct's surroundings, $\left|T(x)-T_{\infty}\right|$. In that case, $\left[T(x)-T_{\infty}\right] \approx\left(T_{A}-T_{\infty}\right)$, and Eq. (A-3) simplifies to

$$
\frac{d T}{d x} \approx-\frac{T_{A}-T_{\infty}}{\lambda} .
$$

The inlet-to-outlet temperature change and the delivery effectiveness are then approximately

$$
T_{A}-T_{B} \approx(\ell / \lambda)\left(T_{A}-T_{\infty}\right)=(\Re / R)\left(T_{A}-T_{\infty}\right)
$$

and

$$
\varepsilon_{C} \approx 1-\frac{c_{p}(\Re / R)\left(T_{A}-T_{\infty}\right)}{H_{A}-H_{R}} .
$$

\section{B. VARIATION Of Fiberglass CONDUCTIVITY WiTh PERMEABILITY AND DUCT AIR SPEED}

If the axial air flow within a duct's internal fiberglass duct insulation is Darcean, its bulk velocity is

$$
v_{f}=-\kappa \frac{d p}{d x},
$$

where $\kappa$ is the permeability of the fiberglass to air, and $p(x)$ is the axial air pressure profile in both the duct cavity and the previously-faced fiberglass. The axial pressure gradient is related to the duct air's axial velocity $v$ by the duct air flow's friction factor, $f$ :

$$
\frac{d p}{d x}=-\frac{f v^{2}}{2 d_{i}},
$$

where $d_{i}$ is the duct's inner diameter. This yields

$$
v_{f}=\frac{\kappa f}{2 d_{i}} v^{2} .
$$

Thus, the velocity in the insulation is proportional to the fiberglass permeability, and-since $f$ is nearly independent of $v$-to the square of the duct air speed. 
If, as a reasonable conjecture, the conductivity of the fiberglass increases linearly with its internal air speed $v_{f}$, the conductivity would rise linearly with the square of the duct air speed:

$$
k_{f}=k_{f 0}\left(1+\text { const } \cdot v_{f}\right)=k_{f 0}\left(1+\gamma_{v} v^{2}\right),
$$

where the velocity sensitivity $\gamma_{v}$ is proportional to the insulation's permeability $\kappa$.

\section{THERMAL RESISTANCES OF AN INTERNALLY-INSULATED DUCT}

\section{Total Resistance Of An Arbitrarily-Shaped Duct}

Using Eq. (A-4), a duct's total thermal resistance $R$ may be calculated from measured values of the duct's inlet and outlet air temperatures:

$$
R=-\Re / \ln \left[1-\left(T_{A}-T_{B}\right) /\left(T_{A}-T_{\infty}\right)\right] .
$$

\section{Air-Film And Insulation Resistances Of A Cylindrical Duct}

The duct's total resistance is the sum of its inner air film, outer air film, and insulation resistances. In a cylindrical duct, these are

$$
R_{i}=1 / h_{i}, R_{o}=\left(r_{i} / r_{o}\right) / h_{o} \text {, and } R_{f}=r_{i} \ln \left(r_{o} / r_{i}\right) / k_{f},
$$

respectively. Here $h_{i}$ and $h_{o}$ are the heat transfer coefficients of the inner and outer air films, and $k_{f}$ is the insulation's effective thermal conductivity (White 1988, p. 65). The heat transfer coefficients may be found in Appendix $\mathrm{E}$ or in heat transfer textbooks (White 1988; Incropera and Dewitt 1990).

Note that the insulation's annular-form resistance, $R_{f}$, is always less than its flat-form resistance, $R_{f, \text { flat }}$. If the insulation's thickness is $\Delta z=r_{o}-r_{i}$, their ratio is

$$
\frac{R_{f}}{R_{f, \text { flat }}}=\frac{r_{i} \ln \left(r_{o} / r_{i}\right) / k_{f}}{\Delta z / k_{f}}=\frac{\ln \left[1+\left(\Delta z / r_{i}\right)\right]}{\Delta z / r_{i}}<1
$$

\section{Air-Film And Insulation Resistances Of A Non-Cylindrical Duct}

Rigid ductwork is often rectangular, rather than circular, in cross section. The thermal resistance components of a rectangular duct may be approximated by those of a circular duct with inner and outer diameters equal to the rectangular duct's inner and outer hydraulic diameters, $d_{h, i} \equiv 4 A_{i} / P_{i}$ and $d_{h, o} \equiv 4 A_{o} / P_{o}$. This technique is commonly used to calculate the convection coefficient for flow inside a non-circular duct (Incropera and DeWitt 1990, p. 461). For convenience, is extended in this study to the computation of all convection coefficients and thermal resistances of non-circular ducts. 


\section{ENTHALPY AND SPECIFIC HEAT OF MOIST AIR}

Using dry air at a reference temperature of $T^{*}=24^{\circ} \mathrm{C}$ as the point of zero enthalpy, the enthalpy of air at temperature $T$ and with humidity ratio $\omega$ is

$$
H=c_{p}\left(T-T^{*}\right)+\omega h_{f g},
$$

where

$$
c_{p}=c_{p, a}+\omega c_{p, w}
$$

is the air's specific heat. At $24^{\circ} \mathrm{C}$, the specific heat of dry air is $c_{p, a}=1.01 \mathrm{~kJ} \mathrm{~kg}^{-1} \mathrm{~K}^{-1}$, the specific heat of water vapor is $c_{p, w}=1.86 \mathrm{~kJ} \mathrm{~kg}^{-1} \mathrm{~K}^{-1}$, and the latent heat of vaporization of water is $h_{f g}=2440 \mathrm{~kJ} \mathrm{~kg}^{-1}$.

\section{E. EMPIRICAL RELATIONS FOR AIR-FILM HEAT TRANSFER COEFFICIENTS}

Inner Air Film

As the speed of the duct air increases, the thickness and the thermal resistance of the boundarylayer air film inside the duct will decrease. The inner air film's forced-convection coefficient $h_{i}$ may be estimated from the Nusselt-number relation for circular ducts (Incropera and DeWitt 1990 , p. 457),

$$
\mathrm{Nu}_{d_{i}}=\frac{h_{i} d_{i}}{k}=\frac{(f / 8)\left(\operatorname{Re}_{d_{i}}-1000\right) \operatorname{Pr}}{1+12.7(f / 8)^{1 / 2}\left(\operatorname{Pr}^{2 / 3}-1\right)} .
$$

Here $d_{i}$ is the duct's inner diameter; $\operatorname{Re}_{d_{i}}=v d_{i} / v_{a}$ is the Reynolds number of the flow inside the duct; $\operatorname{Pr}=v_{a} / \alpha$ is the Prandtl number of air; and $k_{a}, v_{a}$, and $\alpha$ are the thermal conductivity, kinematic viscosity, and thermal diffusivity of air. The friction factor $f$ for air flow inside a rough-walled duct is given by (White 1988, p. 333)

$$
f^{-1 / 2}=-1.8 \log _{10}\left[\left(\frac{\varepsilon_{\text {rough }}}{3.7 d_{i}}\right)^{1.11}+\frac{6.9}{\operatorname{Re}_{d_{i}}}\right],
$$

where $\varepsilon_{\text {rough }}$ is the average wall-roughness height. The roughness height of the inner surface of a lined duct is about $3 \mathrm{~mm}$ (ASHRAE 1997, p. 32.7).

\section{Outer Air Film}

The outer surface of the duct exchanges heat with its surroundings via forced convection, free convection and radiation. The resistance of the air film outside an airtight duct does not explicitly depend on duct air speed, but its rates of free-convective and radiative heat transfer do vary with the temperature of the duct wall. A Nusselt-number relation for forced convection over a long horizontal cylinder is (White 1988, p. 344) 


$$
\overline{\mathrm{Nu}}_{d_{o}, \text { forced }}=\frac{h_{\text {forced }} d_{o}}{k}=0.3+\frac{0.62 \operatorname{Re}_{d_{o}}^{1 / 2} \operatorname{Pr}^{1 / 3}}{\left[1+(0.4 / \mathrm{Pr})^{2 / 3}\right]^{1 / 4}}\left[1+\left(\frac{\operatorname{Re}_{d_{o}}}{282,000}\right)^{5 / 8}\right]^{4 / 5},
$$

where $d_{o}$ is the duct's outer diameter, $\operatorname{Re}_{d_{o}}=v_{\infty} d_{o} / v_{a}$ is the Reynolds number of the air flow outside the duct, $v_{\infty}$ is the air velocity outside the duct, and $h_{\text {forced }}$ is the duct's coefficient of external forced convection.

A Nusselt-number relation for free convection over a long horizontal cylinder is (White 1988, p. 405)

$$
\overline{\mathrm{Nu}}_{d_{o} \text {,free }}=\frac{h_{\text {free }} d_{o}}{k}=\left\{0.60+\frac{0.387 \mathrm{Ra}_{d_{o}}^{1 / 6}}{\left[1+(0.559 / \mathrm{Pr})^{9 / 16}\right]^{8 / 27}}\right\}^{2} .
$$

Here $h_{\text {free }}$ is the duct's free-convection coefficient, $\mathrm{Ra}_{\mathrm{d}_{\mathrm{o}}}=g \beta\left(T_{s}-T_{a}\right) d_{o}^{3} /\left(v_{a} \alpha\right)$ is the Rayleigh number, $g$ is the acceleration due to gravity, $\beta=1 / T_{s}$ is the volume coefficient of expansion of air, $T_{s}$ is the outer air film's temperature, and $\alpha$ is the thermal diffusivity of air. If the flow over the duct is laminar (i.e., $\operatorname{Re}_{d_{0}}<5 \times 10^{5}$ ), a relation for the coefficient of mixed convection (forced plus free) is (White 1988, p. 415)

$$
h_{\text {mixed }}=\left(h_{\text {forced }}^{3}+h_{\text {free }}^{3}\right)^{1 / 3} \text {. }
$$

If an object of surface area $A_{s_{1}}$, emissivity $\varepsilon_{1}$, and absolute temperature $T_{1}$ exchanges radiation with only an enclosure of surface area $A_{s_{2}}$, emissivity $\varepsilon_{2}$, and absolute temperature $T_{2}$, the net radiative heat flow from object to enclosure is (White 1988, p. 487)

$$
Q_{\mathrm{rad}, 1 \rightarrow 2}=\frac{\sigma\left(T_{1}^{4}-T_{2}^{4}\right)}{\frac{1-\varepsilon_{1}}{\varepsilon_{1} A_{s_{1}}}+\frac{1}{A_{1}}+\frac{1-\varepsilon_{2}}{\varepsilon_{2} A_{s_{2}}}},
$$

where $\sigma=5.67 \times 10^{-8} \mathrm{~W} \mathrm{~m}^{-2} \mathrm{~K}^{-4}$ is the Stefan-Boltzmann constant. If the enclosure's area is much larger than that of the object (i.e., $A_{s_{2}} \gg A_{s_{1}}$ ), the heat flow is approximately

$$
Q_{\mathrm{rad}, 1 \rightarrow 2}=A_{s_{1}} \varepsilon_{1} \sigma\left(T_{1}^{4}-T_{2}^{4}\right) \text {. }
$$

Thus, the radiative heat flow from a straight duct to its surroundings is

$$
Q_{\mathrm{rad}}=\varepsilon_{o} \sigma A_{s_{o}}\left(T_{w}^{4}-T_{a}^{4}\right)=\varepsilon_{o} \sigma A_{s_{o}}\left(T_{w}^{2}+T_{a}^{2}\right)\left(T_{w}+T_{a}\right)\left(T_{w}-T_{a}\right),
$$

where $\varepsilon_{o}$ is the outer wall's emissivity, $A_{s_{o}}$ is the outer wall's surface area, $T_{w}$ is the outer wall's temperature, and $T_{a}$ is the enclosure temperature (assumed equal to the air temperature outside the duct). The duct's coefficient of radiative heat exchange with its surroundings may be written 


$$
h_{\mathrm{rad}}=\varepsilon_{o} \sigma\left(T_{w}^{2}+T_{a}^{2}\right)\left(T_{w}+T_{a}\right) .
$$

Since radiation and convection are independent mechanisms, the outer air film's total heat transfer coefficient is $h_{o}=h_{\text {mixed }}+h_{\text {rad }}$. 